\title{
Hydrogeomorphology-ecology interactions in river systems
}

\author{
Robert C. Grabowski ${ }^{1 *}$ and A.M. Gurnell ${ }^{2}$ \\ ${ }^{1}$ Cranfield Water Science Institute, Cranfield University, Cranfield, Bedfordshire, UK \\ ${ }^{2}$ School of Geography, Queen Mary University of London, London, UK \\ * Corresponding author: r.c.grabowski@cranfield.ac.uk, +44 (0)1234758360
}

\begin{abstract}
:
The European Union funded REFORM project has developed guidance and tools aimed at making river restoration and mitigation measures more effective. A major component of this work has been to investigate functional linkages between the hydrogeomorphology and ecology of rivers. This special collection presents some of the outputs from this work which explore interactions between hydrological, geomorphological and ecological processes in naturally-functioning river systems. Together this set of 5 papers review some of the existing knowledge on interactions and feedbacks between hydrogeomorphology and ecology in river systems and outline how hydrogeomorphological processes, ecological processes and plant traits contribute to driving river corridor dynamics that create and sustain a diversity of aquatic and wetland habitats which support fish communities.
\end{abstract}

Keywords: Hydrogeomorphology, biogeomorphology, riparian vegetation, aquatic vegetation, fish 
The dynamic nature of rivers has been long appreciated, but scientific understanding of the geomorphic form-process relationships that are central to the behaviour and condition of a river have been slow to transfer into river management policy and practice. Whilst the river reach has been the primary focus of most management and restoration activities, as this is the scale at which river managers primarily interact with, assess and monitor rivers, the hydrogeomorphologicalcondition of a river reach is influenced by processes operating at larger spatial and longer temporal scales(see reviews by Brierley and Fryirs, 2005; Grabowski and Gurnell, 2014;Gurnell et al., 2015a). In naturally-functioning rivers, the shape of the river reach (planform pattern), the dimensions and configuration of the channel (width,depth), and the geomorphic features that are created in the channel and floodplain (bars, backwaters, etc) are entirely dependent on the interactions between hydrological, geomorphological and ecological processes that cascade down through the catchment and are realised in the specific context of the reach. In rivers that have been directly or indirectly modified by human activity, these processes still occur, but the multi-scale functional links that influence river morphology have been altered(e.g. Downs et al., 2013). The consequences of this disruption are river reaches that are in poor hydrogeomorphological condition and thuslack the physical foundation for fully functioning, connected aquatic, riparian and floodplain habitats. Therefore, the key to the development of sustainable river management and restoration strategies is not to focus on the treatment of the reach-scale symptoms of degradation, but rather to place emphasis on the identification and implementation of process-based solutions at the catchment, or river basin, scale, as proposed byBeechie et al. (2010) and Kondolf et al. (2006). To do this effectively, we need to develop a fuller understanding of the multi-scale interactions between hydrogeomorphological processes and ecological communities.

Early geomorphological studies emphasised the importance of physical factors (e.g. valley and river channel gradient, water and sediment discharge, bed and bank sediment size, etc)in driving channel adjustment and change, and developed conceptual and empirical models of river channel morphodynamics, but more recently, the additional importance of vegetation to the geomorphic functioning of river systems has been recognised(see reviews by Corenblit et al., 2007; Gurnell, 2014). Thus, plant communities play a crucial role in river morphodynamics and ecology, since they both influence and respond to the hydrogeomorphological processes operating in the river and floodplain. In turn, the wider ecological community responds to the increased diversity, frequency and turnover of physical habitats and related flow and biogeochemicalconditions that are influenced by these plant-hydrogeomorphology interactions.

In Europe, the Water Framework Directive (WFD) requires the management of rivers (and other surface waters) in a holistic manner that directly considers chemical water quality, ecological community structure, and hydromorphologicalcondition (note that hydromorphology is the term used within the directive to refer to hydrogeomorphology or hydrology and fluvial geomorphology). The WFD is now the main driver for river restoration within Europe, but an incomplete scientific understanding of the links between physical habitat restoration and ecological status has limited the establishment of best practice. The 'REstoring rivers FOR effective catchment Management' (REFORM) projectwas designed to fill this gap by consolidating the science and developing management tools and guidanceaimed at making river restoration and mitigation measures more effective. A key output of this project isa hierarchical framework to assess hydrogeomorphology that is 
suitable for application across Europe in line with the WFD (Gurnell et al., 2015b), and considers how hydrological, geomorphological and ecological processes interact over multiple spatial and temporal scales to determine the condition of a river reach. As part of the framework development, the interactions between hydrogeomorphology and ecology in naturally-functioning river systemswere exploredand some of the results are presented in this special issue.

In the first paper, Gurnell et al. (2015b)conceptualise how hydrogeomorphological processes and vegetation interact in river corridors acrossthe spatial and temporal scales of the hierarchical framework developed in the REFORM project. A conceptualmodel defines five dynamic zones within river corridors that span a gradient of hydrogeomorphological conditions, represent dominance by different hydrogeomorphological processes and different interactions with vegetation, and whose relative abundance varies from river headwaters to mouth and in association with different river planform types. This work provides a guiding framework with which to interpretvegetation-hydrogeomorphology functioning under both naturally-functioning and human-impacted conditions and thus to incorporate vegetation in sustainable river restoration and management.

The ability of vegetation to act as a hydrogeomorphological agent is dictated by its characteristics or traits. Where vegetation can grow, the form and mechanical properties of its above-ground and below-ground biomass, and how it reproduces all influence how vegetation will respond to and potentially interact with river flows and sediment deposition/erosion. The paper by O'Hare et al. (2015)extends our understanding of hydrogeomorphology-vegetation interactions obtained from previous case studies and conceptual models by developing a typology of hydrogeomorphological function that classifies plant species according to their potential impact on channel conveyance / sediment accumulation and sediment stabilisation. The typology is based on key vegetation traits that mediate vegetation-hydrogeomorphology interactions (soil moisture preference, perennation/winter biomass, size and plant morphology, flexibility, root form, and reproduction and recruitment strategies). The authors demonstrate how the typology can be applied to existing ecological datasets to assess the bioengineering potential of the vegetation community.

Solari et al. (2015) present a start-of-the-art overview of recent research in modelling vegetation-hydrogeomorphology interactions in river systems. Their paper evaluates the latest models that link hydraulic and geomorphological processes with ecological processes, with a focus on four core topics: (i) the effect of vegetation on hydrogeomorphology, (ii) the effectof hydrogeomorphology on riparian vegetation, (iii) interaction between vegetation and hydrogeomorphology, and (iv) interaction between groundwater and vegetation. Within each of these topics the authors summarise the fundamental processes that occur and highlight the models that have been developed to address them. This paper is a resource for modellers and practitioners alike who are looking to advance process-based models of vegetation-hydrogeomorphology interactions or to apply them to river basin management

Gurnell and Grabowski (2015) report on the differing roles that aquatic and riparian vegetation play in driving geomorphic dynamics and adjustment in a low-energy gravel-bed river. Complementing a recent study on the sources and geomorphic impacts of excess fine sediment in the catchment (Grabowski and Gurnell, 2015), the authors present an analysis of historical maps, recent aerial images and field observations to document how vegetation 
is at the leading edge of channel adjustments. Aquatic vegetation located within the channel margins is retaining fine sediment, which stabilises and consolidates into the floodplain to induce channel narrowing and an increase in sinuosity. In reaches with well-developed woody riparian vegetation, living and dead wood create complex hydraulic and geomorphic features. This paper provides important evidence for the key role of vegetation in driving geomorphological adjustments in low energy river systems, and thus emphasises the critical importance of building vegetation into any management plans for such systems.

In the final paper, Wolter et al.(2015) review how fish communities interact with and respond to hydrogeomorphological processes in river systems. The paper first outlines the habitat requirements and life cycle of fish and how these link with the spatial and temporal patterns of habitats within riverchannels. Next, it explores how life cycle adaptations increase the resilience of fish populations to varying hydrogeomorphological conditions (e.g. natural flood events that alter the distribution or availability of habitats). Finally the authors summarise how the spatial scale determines which hydrogeomorphological processes have the greatest influence on fish communities. The paper concludes by noting that while the reach scale is the most appropriate for assessment and direct management of fish communities, consideration of larger scale hydrogeomorphological processes and multiple pressures is essential to the development of sustainable long-term management plans.

\section{Acknowledgements}

The work included in this special issue was funded by the European Union's FP7 programme under grant agreement no. 282656 (REFORM). Further information on the REFORM project and its deliverables is available from http://www.reformrivers.eu/.

\section{References}

Beechie, T.J., Sear, D.A., Olden, J.D., Pess, G.R., Buffington, J.M., Moir, H., Roni, P., Pollock, M.M., 2010. Process-based Principles for Restoring River Ecosystems. Bioscience 60, 209-222.

Brierley, G.J., Fryirs, K.A., 2005. Geomorphology and river management: Applications of the River Styles Framework. Blackwell.

Corenblit, D., Tabacchi, E., Steiger, J., Gurnell, A.M., 2007. Reciprocal interactions and adjustments between fluvial landforms and vegetation dynamics in river corridors: $A$ review of complementary approaches. Earth-Science Rev. 84, 56-86. doi:10.1016/j.earscirev.2007.05.004

Downs, P.W., Dusterhoff, S.R., Sears, W.A., 2013. Reach-scale channel sensitivity to multiple human activities and natural events: Lower Santa Clara River, California, USA. Geomorphology 189, 121-134. doi:10.1016/j.geomorph.2013.01.023

Grabowski, R.C., Gurnell, A.M., 2015. Diagnosing problems of fine sediment delivery and transfer in a lowland catchment. Aquat. Sci. In press. 
Grabowski, R.C., Gurnell, A.M., 2014. Characterizing geomorphological change to support sustainable river restoration and management. WIREs Water 1, 483-512. doi:10.1002/wat2.1037

Gurnell, A.M., 2014. Plants as river system engineers. Earth Surf. Process. Landforms 39, 4-25. doi: 10.1002/Esp.3397

Gurnell, A.M., Corenblit, D., García de Jalón, D., González del Tánago, M., Grabowski, R.C., O'Hare, M.T., Szewczyk, M., 2015b. A conceptual model of vegetationhydrogeomorphology interactions within river corridors. River Res. Appl., this issue, doi:10.1002/rra.2928

Gurnell, A.M., Grabowski, R.C., 2015. Vegetation-hydrogeomorphology interactions in a lowenergy, human-impacted river. River Res. Appl., this issue, doi:10.1002/rra.2922

Gurnell, A.M., Rinaldi, M., Belletti, B., Bizzi, S., Blamauer, B., Braca, G., Buijse, A., Bussettini, M., Camenen, B., Garcia de Jalon, D., Gonzalez del Tanago, M., Grabowski, R.C., Gunn, I., Habersack, H., Hendriks, D., Henshaw, A., Klosch, M., Lastoria, B., Latapie, A., Marcinkowski, P., Martinez-Fernandez, V., Mosselman, E., Mountford, O., Nardi, L., Okruszko, T., O'Hare, M., Palma, M., Percopo, C., Surian, N., van de Bund, W., Weissteiner, C., Ziliani, L., 2015a. A multiscale framework for developing understanding of river behaviour to support river management. Aquat. Sci. in press.

Kondolf, G.M., Boulton, A.J., O'Daniel, S., Poole, G.C., Rachel, F.J., Stanley, E.H., Wohl, E., Bang, A., Carlstrom, J., Cristoni, C., Huber, H., Koljonen, S., Louhi, P., Nakamura, K., 2006. Process-based ecological river restoration: Visualizing three-dimensional connectivity and dynamic vectors to recover lost linkages. Ecol. Soc. 11, 5. [online] URL http://www.ecologyandsociety.org/v.

O'Hare, M.T., Gunn, I., Mountford, O., 2015. Plant traits relevant to fluvial geomorphology and hydrological interactions. River Res. Appl., this issue.

Solari, L., Van Oorschot, M., Belletti, B., Hendriks, D., Rinaldi, M., Vargas-Luna, A., 2015. Advances on Modelling Riparian Vegetation-Hydromorphology Interactions. River Res. Appl., this issue, doi:10.1002/rra.2910

Wolter, C., Buijse, A., Parasiewicz, P., 2015. Temporal and spatial patterns of fish response to hydromoprhological processes. River Res. Appl., this issue. 